\begin{tabular}{ll}
\hline \hline MINING AND METALLURGY INSTITUTE BOR & ISSN: 2334-8836 (Štampano izdanje) \\
UDK: 622 & ISSN: 2406-1395 (Online) \\
\hline \hline
\end{tabular}

\title{
IMPORTANCE OF PLANNING THE OPEN PITS IN THE CONDITIONS OF CONTEMPORARY MINING - A CASE STUDY: THE OPEN PIT SOUTH MINING DISTRICT MAJDANPEK ${ }^{*}$
}

\begin{abstract}
In today's financial and environmental climate, it is imperative to develop the robust projects with good economics. Successful business in conditions of limited resources is impossible without analyzing all the technical and economic parameters and scenarios of sustainable operation. In this sense, it requires the application of mathematical algorithms implemented in the contemporary software tools able to efficiently provide the effective troubleshooting of design in complex conditions of modern mining.

This paper, an example of the open pit South Mining District Majdanpek, shows the importance of planning and design the ore exploitation in achieving the maximum net present value (NPV).

Keywords: planning, optimization, net present value, open pit South Mining District Majdanpek
\end{abstract}

\section{INTRODUCTION}

Mine planning is aimed at one goal: maximizing the value to be realized from extracting the mineral resources. This goal achievements depends primarily on the ability of an engineer to realize the all issues related to the production process in terms of the number of alternatives related to the investment and exploitation factors. The decisions are updated through time, usually annually, as a new information becomes available.

The size, location and final shape of an open pit are important in planning the location of waste dumps, stockpiles, processing plant, access roads and other surface facilities, and for development the production program. The pit design also defines the minable reserves and associated amount of waste to be removed during the operation life. Over the past 50 years, determining the optimum open pits has been in the areas of operational research in the mining industry.y and many algorithms have been published.

The design and scheduling of open pit mines is a significant and complex problem in the mine planning. The principal aim of mining operation is to ensure that an ore body is exploited in a way such that the value realized from the mine is maximum. A well-known early contribution to this field was made by Lerchs and Grossmann [8], who presented a graph-theoretic algorithm for determining the final con

\footnotetext{
* Mining and Metallurgy Institute Bor,e-mail: daniel.krzanovic@irmbor.co.rs

** University of Belgrade, Technical Faculty in Bor

*** The work is the result of the Project TR 33038 ,Improvement the Technology of Copper Ore Mining and Processing with Monitoring of Living and Working Environment in RTB Bor Group ", funded by the Ministry of Education, Science and Technological Development of the Republic of Serbia
} 
tour of the open pit, known as the ultimate pit, such that the total profit from the mine is maximized.

Some optimization methods for solving problems of mine scheduling are the heuristics (Gershon [1]), dynamic programming (Onur and Dowd [2], Wang [3], parametric methods (Whittle [4]), Tolwinski and Underwood [5], Tolwinski i Golosinski [6]), integer linear programming (Gershon [7], Smith [8], Caccetta and Hill [9]) and Mixed Integer Linear Programming - MILP (Vahid Rafiee i Omid Asghari [10]).

\section{METHODOLOGY}

Mining processes are complex and complicated, with many different economic, technical, environmental and other parameters that must be planned before the project gets its practical value. Many of these parameters are evaluated independently of the other, due to the expediency and difficulty in predicting the values of variables under consideration. Costs, prices, reserves, ore mining and processing, as well as many aspects of society, such as the issuance for implementation of works are absolutely essential for the project evaluation.

Each ore body is different, but the main steps in the open pit planning, when the main objective is the maximization of NPV, take place on the same principle. These steps are for simplicity represented as linear. The actual planning process is an iterative process in which some steps or combination of steps are repeated many times with the sensitivity analysis.

Achieving the maximum NPV is realized by the procedure which comprises first the optimization of open pit and defining the phase of open pit development (pushbacks) with calculation the ore amount and mineral content in each phase. The next step is to optimize the mining dynamics.

Blok model of deposit, created by the method of geostatistical modeling, with separate areas of useful mineral blocks and non-profit blocks of waste, allows engineers to select the appropriate mining methods and plan the necessary equipment and infrastructure that are essential for development the process of ore mining. Blok model of deposit is a major input in the optimization process of the open pit.

Optimization of the open pit comprises obtaining a possible contour of the open pit, based on a block model of deposit, which has an economic value, and which can be calculated. The term a possible contour of the open pit means an open pit contour with maximum inclination of general slope, formed after mapping the transport routes and safety berms, and which meets the stability criteria.

To calculate the economic value, the sequence of excavation has to be firstly defined, and then, progressively with excavation, to accumulate the income and expenses. Application the principle of the time value of money, or that a dollar that is obtained today, is more valuable than the one that will (maybe) be obtained next year, means that discounting of revenue and costs is done by a factor that increases over the life of the mine.

Another thing to note is that the calculation of values is made for each block in the block model, or each block has its economic value. Calculation the economic value of the block (EVB) requires a detailed knowledge of a large number of parameters, such as the content of useful component in a block, the selling price of useful component, the costs of mining and processing, cut-off grade in mining and processing, recoveries in mining and processing.

Today's the open pit optimization techniques, which are implemented in specialized software, finding the optimal contour of the open pit are based on maximizing the NPV. This ensures that there is no independent block or combination of blocks that can be added or subtracted within the contour of the pit, which would lead to an increase in the NPV. 
Optimization the open pit limit and mining dynamics was carried out in this work using Whittle software. Whittle process is based on a rapid implementation the series of the Lerchs-Grossmann (LG) algorithm. This algorithm provides the mathematically optimal ultimate open pit limit when the criterion for optimization is the maximum undiscounted cash flows. The process is used for selection the optimum final pit limit for the best and worst case of the mining excavation plans for which the NPV curves are obtained. A wide range of possible open pits is generated by this way including an engineer selecting the optimum open pit, which once again confirms that an engineer still has an irreplaceable role in design despite the a strong software development and computer equipment.

In the process of optimization of mining dynamics, a simulation and discounted cash flow analysis (DCF) are done to obtain the most favorable solution, that is, to determine the number of phases which affects maximization of the net present value in a long - term planning of the open pits.

The analysis is based on the Milawa algorithm, which is specifically designed to optimize the mining dynamics in the longterm planning strategy of mining.

The Net Present Value is calculated by discounting the estimated annual cash flows at the current time using the discount rate, which represents the risk of investment.

$$
\text { Net Present Value }(\text { NPV })=\sum_{t=0}^{N} \frac{\operatorname{Cash} F \text { low }(C F)}{(1+k)^{t}}
$$

where:

$$
\mathrm{k} \text { - discount rate }
$$

$\mathrm{t}$ - number of years.

The importance of planning the open pits is seen in the case of the open pit South Mining District Majdanpek in which the copper ore is mined. The analysis of mining dynamics for current real indicators of mining conditions at the open pit and designed mining dynamics, and within the framework of the project defined the optimal contours of the open pit, has shown how the business operations of a mining company is sensitive to the changes in mining production.

\section{CASE STUDY}

The open pit South Mining District of the Copper Mine Majdanpek is located in the south of the town of Majdanpek in its immediate vicinity. Mining of copper ore at the open pit South Mining District is carried out using a discontinuous technology of excavation, using the drilling - blasting works and loading - transport machines.

The open pit South Mining District operates within the company Copper Mine Majdanpek, which is part of the company Mining and Smelting Basin Bor Group (RTB Bor Group).

In 2013, the project was developed that reviewed the long-term development of the open pit South Mining District Majdanpek [11]. Input data for defining the final limits of the open pit and mining dynamics in the software Whittle are provided in the following Table 1. 
Table 1 Techno-economic data for analysis [11]

\begin{tabular}{|c|c|c|}
\hline Parameter & Unit & Value \\
\hline \multicolumn{3}{|l|}{ Base metal prices } \\
\hline - Copper & $\$ / \mathrm{t}$ & 6,000 \\
\hline - Gold & $\$ / \mathrm{kg}$ & 35,000 \\
\hline - Silver & $\$ / \mathrm{kg}$ & 650 \\
\hline Costs of ore mining & $\$ / \mathrm{t}$ & 1.50 \\
\hline Costs of waste mining & $\$ / \mathrm{t}$ & 2.50 \\
\hline \multicolumn{3}{|l|}{ Costs of flotation ore processing } \\
\hline - Up to 2014 & $\$ / t$ & 4.00 \\
\hline - Period after 2014 & $\$ / \mathrm{t}$ & 3.20 \\
\hline \multicolumn{3}{|c|}{ Costs of metallurgical treatment of concentrates } \\
\hline \multicolumn{3}{|c|}{ - Costs of copper production from concentrates } \\
\hline-2013 & $\$ / \mathrm{t} \mathrm{Cu}$ cathode & 850 \\
\hline - Period after 2013 & $\$ / \mathrm{t} \mathrm{Cu}$ cathode & 600 \\
\hline - Costs of gold refining & $\$ / \mathrm{kg}$ & 150 \\
\hline - Costs of silver refining & $\$ / \mathbf{k g}$ & 15 \\
\hline \multicolumn{3}{|l|}{ Flotation copper recovery from ore } \\
\hline - Up to 2014 & $\%$ & 80 \\
\hline - Period after 2014 & $\%$ & 86 \\
\hline \multicolumn{3}{|c|}{ Metallurgical copper recovery from ores } \\
\hline - Up to 2014 & $\%$ & 94 \\
\hline - period after 2014 & $\%$ & 98 \\
\hline Total recovery of gold & $\%$ & 50 \\
\hline Total recovery of silver & t/year & 50 \\
\hline Annual processing capacity of ore & t/year & $8,500,000$ \\
\hline Discount rate & t/year & 10 \\
\hline
\end{tabular}

The basic problem of production system at the open pit, in the period from 2013 to the present day, is related to a delay in relocation the major infrastructure facilities, located in a newlydefined contour of the open pit (the route of the state road M22 I B series, a part of the route of the existing $35 \mathrm{kV}$ transmission line, the riverbed of the river Mali Pek, the urban waste water collector), as well as pumping of the mine water, whose starting level was at a height of $\mathrm{k}+221$, and these are amounts of $15,136,286 \mathrm{~m}^{3}$. This caused a delay in the ore stripping and therefore deviation from the designed solutions and parameters that guarantee the maximum NPV, which is verified by the techno-economic analysis of the project.
The conducted analysis is aimed to determine the resulting implications in the company business, which is reflected primarily in the lost profit due to deviations from the optimal mining dynamics defined by the mining project.

The amount of ore and overburden in the early years, from the first to the fifth year, represent the real amounts, excavated at the open pit South Mining District Majdanpek [12].

Geological reserves of the copper deposit South Mining District Majdanpek are calculated by the method of mini blocks, sizes $15 \times 15 \times 15 \mathrm{~m}$. The basis for calculation the geological reserves is a digital block model of the deposit which was formed in the software Gems [13, 14]. Geostatistical 
method that, used to assess the content of metals in the process of deposit modeling is a method of real kriging.
Figure 1 shows a three-dimensional block model of $\mathrm{Cu}$ in the deposit South Mining District.

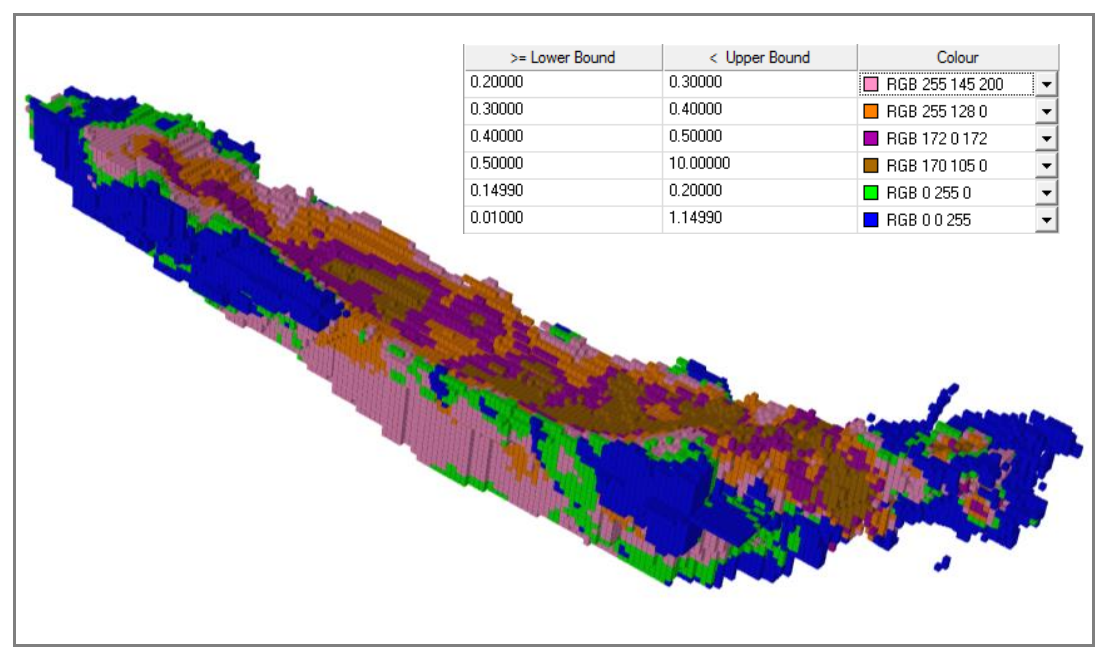

Figure 1 View the 3D block model of the deposit South Mining District Majdanpek

On the basis of a defined block model of the deposit, the optimization of the final contour of the open pit was done in the software Whittle and defined development phases of the open pit; six pjases are defined, wherein the sixth phase is the final contour of the open pit, Figure 2.

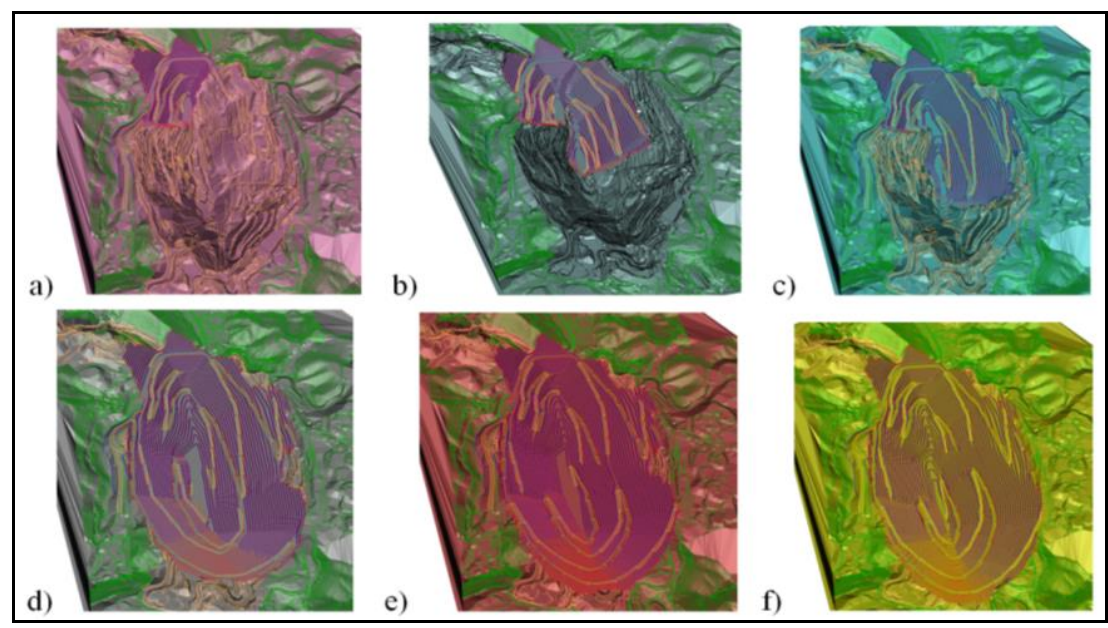

Figure 2 View of the final contour of the open pit mining South Mining District Majdanpek (3D) [15]

a) Phase 1; b) Phase 2; c) Phase 3; d) Phase 4; e) Phase 5; f) Phase 6 (final contour of the open pit) 


\section{RESULTS AND DISCUSSION}

Maximization of the NPV of the project in the life time of the mine was carried out by optimization the mining dynamics.
The results of carried out analysis are shown in the following graphs in Figures 3 and 4.

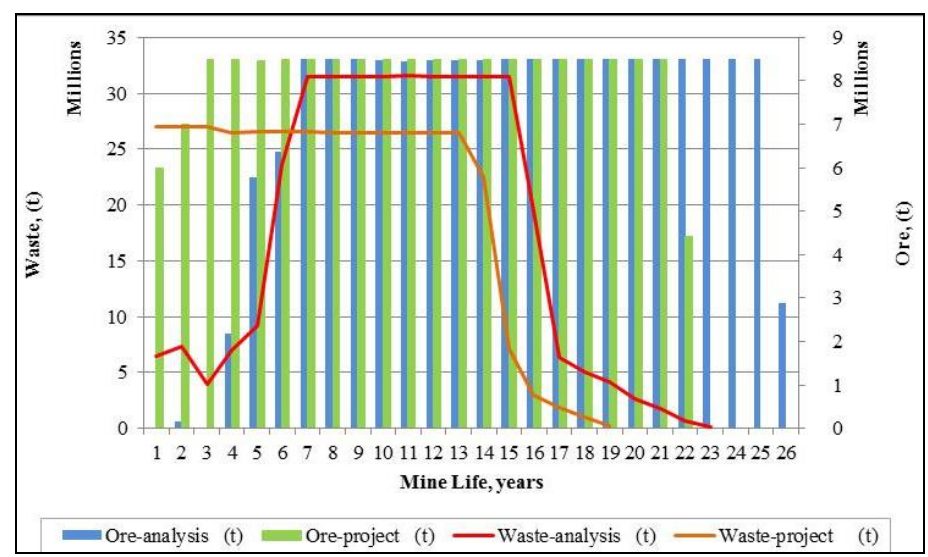

Figure 3 Mining dynamics for the project design and conducted analysis

The following can be concluded from the graph in Figure 3:

1) During the period from the first to the sixth year, significantly lower amounts of ore and overburden were mined relative to the designed amounts.

2) The amounts of overburden arebalanced by the project, which in the period up to $13^{\text {th }}$ year have a uniform value, and then decline steadily until the end of mining life.

3) The conducted analysis shows that it is necessary to significantly increase the annual amounts of overburden to achieve the required capacity of ore mining.

4) The lifetime of the mine was increased by 4 years, while the amounts of ore and overburden are the same.

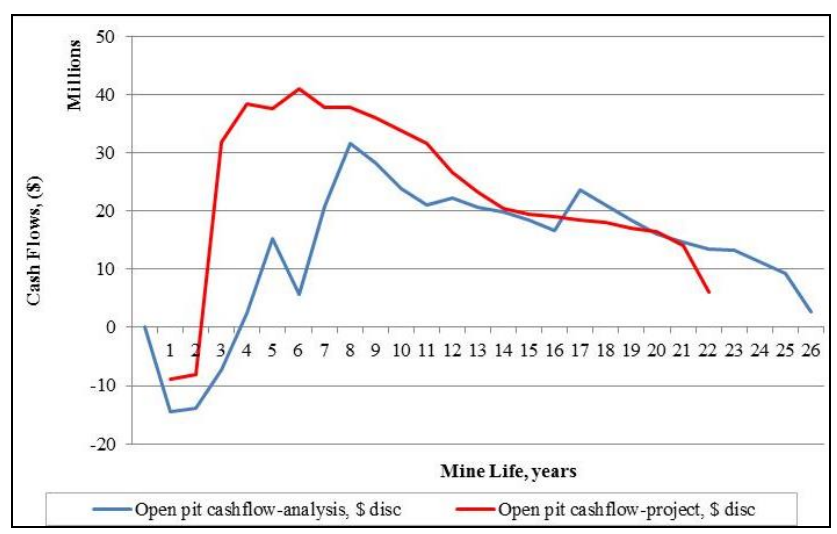

Figure 4 Cash flows for the project design and conducted analysis 
Graph in Figure 4 indicates the following:

1) Cash flows in the period up to $3^{\text {rd }}$ year of mining are negative for the conducted analysis and total to $35,771,590 \$$. In the project design, the negative values of cash flows are up to $2^{\text {nd }}$ year of mining and amount to $\$-16,912,075$.

2) The curve of cash flows for the conducted analysis, after reaching a positive value grows much slower and has less value compared to the curve of cash flows for the solution provided in the project.

Based on the generated cash flows, the maximum NPV are calculated and to be achieved in the following cases:

- NPV obtained by the project design is $507,621,108 \$$,

- NPV obtained by the conducted analysis is $354,763,334 \$$.

Due to a deviation from the given solution in the project, or the planned mining dynamics, there was a realization of smaller cash flows in the initial years of operation and longer mining life of the open pit, what have also increased the discounting time that has a significant reduction in the NPV in the amount of $152,857,774 \$$ in the end result.

\section{CONCLUSION}

Planning every mining operation has the main goal to achieve the best economic effects of business in the life time of the mine. Also, the mining company may want to simultaneously maximize the NPV, the life time of the mine and metal content in the ore, and on the other hand to minimize the capital expenditures, which is difficult to achieve. The most common case is that the main objective of the company is to maximize the NPV, and that the life time, reserves and capital costs are in certain acceptable limits.
The main value of the conducted analysis is that the real case shows how important it is the planning in the mining system in terms of achieving the best business results. Analysis indicates that any deviation from the planned solutions in a project can lead the business to be affected, not only mine, but also the entire company of RTB Bor Group.

Analysis has showed that the deviation from the planned mining dynamics, within the project defined optimal contour of the mine, resulting in a reduction the projected values of the NPV for $30 \%$, or $152,857,774 \$$.

\section{REFERENCES}

[1] E. M. Gershon, An Open - Pit Production Scheduler: Algorithm and Implementation, Mining Engineering 39 (1987) 793-796.

[2] A. H. and P. A. Onur Dowd, Open-Pit Optimization - Part 2: Production Scheduling and Inclusion of Roadways, Transactions of the Institute of Mining and Metallurgy Section A 102 (1993) A105-A113.

[3] Wang Q., Long - Term Open - Pit Production Scheduling Through Dynamic Phase - Bench Sequencing, Transactions of the Institute of Mining and Metallurgy Section A 105 (1996) A104-A99.

[4] Whittle J., The Facts and Fallacies of Open Pit Optimization, Whittle Programming Pty., Ltd., North Balwyn, Victoria, Australia. 1989,

[5] B. Tolwinski and R. Underwood, A scheduling Algorithm for Open Pit Mines, IMA Journal of Mathematics Applied in Business 7 and Industry (1996) 247-270.

[6] Tolwinski B. and Golosinski T. S., 1995, Long Term Scheduler Open Pit, in Proceedings of the International 
Symposium on Mine Planning and Equipment Selection, p. 256-270.

[7] E. M. Gershon, Mine Scheduling Optimization with Mixed Integer Programming, Mining Engineering 35 (1983) 351-354.

[8] M. L. Smith, Optimizing Inventory Stockpiles and Mine Production: An Application of Separable and Goal Programming to Phosphate Mining Using AMPL/CPLEX, CIM Bulletin 921030 (1999) 61-64.

[9] L. S. Caccetta and P. Hill, An Application of this Branch and Cut Open Pit Mine Scheduling, Journal of Global Optimization 27 (2003) 349-365

[10] V. Rafiee, Asghari, O., 2008, A Heuristic Traditional MIP Solving Approach for Long Term Production Scheduling and Open Pit Mine, Journal of Applied Science 8 (24), pp. 4512-4522.

[11] D. Kržanović et all, Supplementary Mining Project of the Copper Ore Mining from the Deposit South Mining District of the Copper Mine Majdanpek, Mining and Metallurgy Institute Bor, 2013 (in Serbian)

[12] Source: Group RTB Bor
[13] D. Kržanović, M. Žikić, R. Pantović Important Improvement of Utilization the Available Geological Reserves of the South Mining District Deposit Majdanpek and the New Defined Optimum Contour of the Open pit using the Whittle and Gemcom Software, Mining Engineering - Mining Engineering, Mining and Metallurgy Institute Bor, 2012, pp. 29-36

[14] D. Kržanović, M. Žikić, Z. Vaduvesković: Innovated Block Model of the Copper ore Deposit South Mining District Majdanpek as a Basis for Analysis the Optimum Development of the Open Pit Using the Software Packages Whittle and Gemcom, Mining Industry - Mining Engineering, Mining and Metallurgy Institute Bor, 2011, pp. 69-76

[15] D. Kržanović, R. Rajkovic, M. Mikić, M. Ljubojev, Analyzing the Possibility of Increasing Capacity of Copper Ore Mining at the Open Pit South Mining District Majdanpek at $11 \times 10^{6} \mathrm{t}$ Annually, Mining and Metallurgy Engineering Bor, 3/2015, Mining and Metallurgy Institute Bor, pp. 73-80. 